\title{
Os blogs como ferramenta para a educação musical
}

\section{Adriana N. A. Mendes (PQ), Patricia Kawaguchi Cesar (IC).}

\section{Resumo}

O propósito desta pesquisa foi analisar os blogs como uma ferramenta para a educação musical, mostrando como os professores podem usar essa tecnologia como aliada dentro e fora da sala de aula. De forma prática, analisou dois blogs: o primeiro é um blog público onde a autora escreve sobre música em geral e o segundo foi um blog colaborativo privado construído com os alunos da disciplina de pedagogia musical da Unicamp. A autora também escreveu um manual sobre criação e manutenção de um blog.

Palavras Chave: blog, educação musical, internet.

\section{Introdução}

Os jovens são grandes entusiastas da Internet e da tecnologia, por isso o professor deve acompanhá-los na exploração das ferramentas. Nesse novo paradigma, o professor estimula os alunos a fazer as buscas e ajuda-os a entender o que foi encontrado, enfim, usa a tecnologia a seu favor para complementar as aulas, tornando-as mais interativas. "O papel do professor - o papel principal - é ajudar o aluno a interpretar esses dados, a relacioná-los, a contextualizá-los." 1

Dentre as opções que temos na Internet para ler e escrever, destaca-se o blog. Uma das vantagens de utilizar essa ferramenta ao invés de um site normal é que o blog apresenta mais interatividade e proximidade com o leitor. É possível deixar comentários, estabelecendo um contato com o autor para poder exprimir sua opinião ou tirar dúvidas. Acontece assim uma empatia do leitor pelo autor e o blog passa de um monólogo a um diálogo. ${ }^{2}$

O blog oferece também uma oportunidade de socialização entre professores e alunos em um espaço mais informal. O contato com o professor não ocorre apenas no horário da aula, mas pode se ampliar remotamente para qualquer dia $\mathrm{e}$ horário da semana em que os alunos acessarem a página para lerem, postarem ou discutirem.

\section{Resultados e Discussão}

O blog colaborativo usado de forma complementar à aula foi uma novidade; embora os alunos tenham achado uma ferramenta interessante, não foi possível explorar todas as possibilidades que ele tinha a oferecer nas disciplinas de pedagogia e didática musical devido ao cronograma corrido. Seria preciso repensar uma forma de usá-lo com mais eficácia.

Através do questionário no blog da autora, foram obtidos os seguintes resultados: O primeiro acesso ao blog se dá em sua maioria ou através de um mecanismo de busca na Internet ou por conhecer a autora. Isso comprova o alcance que os mecanismos de busca dão ao blog e a eficácia da divulgação do blog para os colegas de curso, além de apresentá-lo em encontros de educação musical. Os leitores se dividem quase que ao meio entre os que nunca estudaram música e os que estudam ou já estudaram, o que mostra que o blog tem um público heterogêneo. A maioria não tem blog, embora alguns afirmem ter interesse em eventualmente criar um.

\section{Conclusões}

A partir da apresentação do trabalho em diversos congressos e da experiência com o blog colaborativo, percebi que o uso dessa ferramenta ainda é uma novidade na área da educação musical. O público, entretanto, se mostrou muito receptivo e interessado em todas as ocasiões, o que me faz acreditar que o manual para a criação e manutenção de blogs, desenvolvido como produto desta pesquisa, poderá incentivar outros educadores a criarem blogs, aumentando assim o compartilhamento de informações.

\section{Agradecimentos}

Agradeço minha orientadora e professora Adriana Mendes, por sempre me apoiar e por tudo o que me ensinou. Agradeço o PIBIC/CNPq por tornar possível a realização dessa pesquisa. Agradeço também os leitores do blog por me motivarem a continuar compartilhando um pouco do meu trabalho.

MORAN, José M. A pedagogia e a didática da educação on-line. In: SILVA, Ricardo V; SILVA, Anabel V. Educação, aprendizagem e tecnologia: um novo paradigma para professores do século XXI. Lisboa: Edições Sílabo, 2005. p. 67-93.

${ }^{2}$ LARA, Tíscar. Blogs para educar: usos de los blogs en una pedagogia constructivista. Revista Telos, Madrid, n. 65, p. 86-93, 2005. 